\title{
AUDIT EXEMPTION FOR MALAYSIAN SMEs: DOES OWNERSHIP MATTER?
}

\author{
Engku Ahmad Khairuddin Engku Mohd Anuar, S. Susela Devi ${ }^{1}$ and \\ Chan Wai Meng
}

\begin{abstract}
Small and medium-sized enterprises (SMEs) are playing an increasingly important role in the process of industrialization in the developing world. To support SMEs, many developed countries, such as Australia, New Zealand and the United Kingdom, have implemented an audit exemption regime for SMEs, while, in Malaysia, the policy makers and regulators have announced that the audit for SMEs will remain a legal obligation that they will revisit sometime in the future. Thus, this paper aims to shed light on this issue by exploring the relationship between the ownership structure of SMEs and audit exemption. The objective is to determine whether SMEs will still opt for an audit if it becomes voluntary, and, if they do, what would be the reason for the sampled SMEs to behave in such a manner? This research is exploratory in nature and employs the questionnaire survey method to collect data from a random sample of 200 SMEs in both the manufacturing and service industries. The survey results indicate that there is a significant difference between the ownership structure of firms and the decision of SMEs to opt for voluntary audit. Moreover, the lack of resources is significantly related to opting for a voluntary audit. Therefore, based on the resource-based theory, SMEs in Malaysia mainly opt for auditing, not to fulfil a mandatory obligation but to compensate for their lack of tangible (professional/qualified accountants) and/or intangible (accounting and business expertise) resources. This study provides new insights into the way Malaysian SMEs view auditing. It highlights the implications of the policy directives of the Malaysian regulators and the accounting fraternity. Furthermore, the Malaysian experience is useful for consideration by other developing nations that are contemplating moving towards an audit exemption regime.
\end{abstract}

Keywords Auditing, SMEs, Agency theory, Resource dependency theory, Resource-based view, Malaysia

\footnotetext{
Corresponding author: Dr Susela Devi is a Professor at the Faculty of Business and Accountancy, University of Malaya, email: susela@um.edu.my. Dr Chan Wai Meng is a Senior Lecturer at the Faculty of Business and Accountancy, University of Malaya.
} 


\section{Introduction}

In this globalised era, many developed countries, such as the United States, the United Kingdom, Australia, New Zealand and Singapore, have already implemented a regime of audit exemption for small and medium-sized enterprises (SMEs). In the United States, there is no statutory audit requirement except for listed companies in compliance with the requirements by the Securities and Exchange Commission (SEC). However, in many of the Commonwealth countries (e.g. Pakistan, India and Malaysia), audits are mandated for all registered companies (with some exceptions for exempt private companies and dormant entities). Increasingly, there is a growing realization that smaller businesses need not be subject to the stringent audit requirement imposed on larger businesses with public accountability. In 2003, Singapore took steps to exempt the audit of smaller businesses. Many countries, such as India, Pakistan, Hong Kong and Malaysia, are still debating the issue of audit exemption for SMEs.

Overall, the benefits of auditing have been widely supported by the agency theory (Wallace, 1980; Ng, 1978; Jensen and Meckling, 1976). However, as the literature on the association between the separation of ownership, control, and the demand for auditing is quite inconclusive, there is a demand for more empirical research to be conducted (Seouw, 2001; Senkow et al., 2001; Carey et al., 2000; Barfield et al., 1993; Chow, 1982). In view of the fact that SMEs generally exhibit lower levels of agency conflict (Carey et al., 2001), there are a number of reasons they may opt for an audit. The primary explanation of demand for auditing is that it serves as a monitoring role, which enhances the credibility of financial information (Carey, 2010). Traditionally, auditors provide advice to management, either by raising issues pertaining to internal control discovered through the process of an audit (Arens and Loebbecke, 1976), or by assisting the owner-managers of SMEs to control their business (Abdel-Khalik, 1993). Moreover, since external accountants have progressively developed a broader business perspective (Fogarty et al., 2006; Greenwood et al., 2002), they are able to provide their clients with business advice from a fresh perspective and improve their performance level. This is also encouraged by the fact that there are no legislative restrictions in the SME environment on auditor-provided business advisory services either as a separate service or as part of the external audit.

In addition to the agency theory, this study draws on another two management theories - resource dependency theory and resource-based viewthat are applicable to auditing, the benefits of which are mentioned above. First, based on the 'resource dependency theory', limitations on the availability of resources foster specialization and necessitate organizational interdependence, thereby creating resource dependencies (Ulrich and Barney, 1984; Cook and Emerson, 1984; Pfeffer, 1981; Pfeffer and Salancik, 1978; Cook, 1977). In view of the beneficial role played by auditing firms in providing specific services to SMEs, the limitations on the part of SMEs have been revealed. It can be recognized that Malaysian SMEs might fall short of the standard accounting qualities concerning 
expert knowledge or business consultancy, which are intangible resources already available in auditing firms.

Secondly, the resource-based view of the firm conceptualizes the enterprise as a "bundle of unique resources" (Penrose, 1959). Therefore, the growth of the firm is both facilitated and limited by management's search for the best usage of available resources (Penrose, 1959). These include tangible and intangible, human and non-human resources that are possessed or controlled by the firm and that permit it to devise and apply value-enhancing strategies (Barney, 1991; Wernerfelt, 1984). The resource-based view sees resources as inherently valuable, and holds that the firm's unique resources should define the essence of strategy (Spanos and Lioukas, 2001; Kamyabi and Devi, 2011). Taking this perspective also entails that "the dynamic capabilities" of a firm are "an aid to management endeavoring to gain competitive advantage" (Teece et al., 1997). Dynamic capabilities equip the firm with the "ability to integrate, build, and reconfigure internal and external competencies to address rapidly changing environments" thus achieving competitive advantage (Teece et al., 1997).

Therefore, based on the theoretical background, we can infer that, theoretically, there would be a relationship between these three theories and the willingness to opt for voluntary audit when exemption is offered. Surprisingly, this has hardly been the case in the field of accounting, more specifically in the context of Malaysia, the resource-based view and resource dependency theory, and their interface are being adopted to examine the relationship between SMEs having sufficient accounting resources and the capabilities to deploy them in relation to audit issues. Accounting resources here refer to professional accounting know-how, expertise, human resource, and budget

The originality of this study comes from its ability to fill this gap by addressing the intriguing question of whether Malaysian SMEs will opt for a voluntary audit when exemption would be an option; this has been an issue in Malaysia since the early 1990s (Abdul Aziz, 2002). Thus, it can be hypothesized that their lack of accounting resources necessitates organizational interdependence, which, in turn, creates resource dependency. This resource dependency is the influencing factor that leads to a 'voluntary audit' when given the option of whether or not to audit. Now, as the regulators and policy makers are bewildered concerning whether to making the audit for SMEs a voluntary task or a mandatory requirement, the results of this study provide enlightenment.

\section{Research Background}

\subsection{Corporate Governance and Audit Requirement}

The theory that has been widely quoted in the literature to explain the function of audit is the 'agency theory' as propounded by Jensen and Meckling (1976). In a firm, the management is separated from its ownership. The management is in the hands of the board of directors, who are appointed by the shareholders at 
their annual general meeting. As the directors' interests may not be aligned with those of the shareholders, the audit function serves to provide credibility to the financial statements presented by the directors to the shareholders.

The board, or any of the directors, may be removed by the shareholders at a general meeting, as the directors, being the agents, are answerable to their principals, i.e. the shareholders. Thus, there are provisions in the company legislation requiring a company to call for a general meeting at least once a calendar year. At the meeting with the shareholders, the board of directors is supposed to give an account of the company's affairs to the shareholders, which include the company's financial information.

The financial statements form the basis for evaluation by shareholders of the company's financial position and performance. However, this method may not be fool proof, as the directors have control over the manner of presenting the financial information and its contents (Sikka, 2009). The risk of dishonesty on the part of the directors is real, thus giving rise to the agency theory (Jensen and Meckling, 1976). The information asymmetry between the directors and the shareholders and the moral hazard risk are factors motivating the shareholders to willingly incur costs to monitor the activities of their agents, i.e. the directors of the firm. One way is to have an independent third party to review the financial information, a device welcomed by both parties. To the principal, the financial statements provided by the agent have been attested by an independent auditor, and, to the agent, the audit confirms the quality of information provided to his principal (Tabone and Baldacchino, 2003).

The agency theory might have caused the enactment of the first mandatory audit provision in English in 1879, as an aftermath of a financial scandal. Section 7 of the Companies Act 1879 was enacted to restore the public's confidence in the banking industry after the collapse of the City of Glasgow Bank, which falsified its accounts to ensure that it remained an investor's favourite.

The agency theory is more relevant and applicable in a complex set-up in which the directors have only a minor stake in the firm, and, thus, may work towards maximizing their personal gains instead of the shareholders as a body. Despite that, the audit requirement was subsequently extended to all firms through section 21 of the English Companies Act 1900. This was to ensure that the shareholders received reliable and accurate information that reflects the company's financial position, as the financial information has to be examined by a third party, i.e. an auditor. The audit requirement was adopted by the legislatures in most, if not all, Commonwealth countries, and Malaysia was no exception.

A century after the introduction of the mandatory audit in the UK, steps were taken to reverse the requirement for selected companies with effect from 1981. Under section 12 of the UK Companies Act 1981, a dormant company is exempted from this requirement. Additional costs, as a result of the implementation of a directive on auditors' qualifications, further liberalized the statutory requirement. In 1994, the UK Companies Act 1985 (Audit Exemption) Regulations 1994 were 
passed to exempt small companies from annual audits despite opposition from the Inland Revenue and bankers. Through the years, the tests for a "small company", which were based on the size of its balance sheet, turnover and workforce, went through many changes. In 1994, the maximum turnover for a small company was $£ 90,000$; this was gradually increased to $£ 300,000$ and $£ 1$ million in 1997 and 2000, respectively, and raised to $\$ 5.6$ million under section 477 of the UK Companies Act 2006.

It should be stressed that the legislature recognizes the relevance of the agency theory, for such exemption is subject to the overriding rights of the shareholders to demand an audit. Section 476 of the UK Companies Act 2006 provides that shareholders holding at least $10 \%$ of the company's issued capital may require the company to have its accounts audited. Thus, it is to be expected that where the directors have a minor stake in the company, the shareholders would require the accounts to be audited. This is supported by Tauringana and Clarke (2000), and Collis et al. (2004).

\subsection{Evolution of Businesses and Impact of Globalization}

Much focus has been directed on fine-tuning the audit practice. The International Federation of Accountants (IFAC) has been issuing guidance on auditing since 1979. ${ }^{2}$ Initially, these were known as International Auditing Guidelines. However, subsequent to the many notable corporate debacles (for example, Enron and WorldCom), the authority of these guidelines was enhanced, and, subsequently, renamed the International Standards on Auditing (ISAs). The Standards apply to audits conducted on big and small businesses. The rationale being that "one size fits all".

Many member bodies of IFAC and their respective members, especially small medium practitioners ("SMPs") and members of the profession from developing nations, struggle to cope with the complexities and volume of international standards (IFAC 2004). This has brought forth the issue concerning the relevance of audits for small businesses.

The issue of 'relevance' arises from the fact that the International Standards on Audit (ISAs) were chiefly written for public listed companies, and, thus, have eroded the relevance of ISAs to SME audits. The complexity and large entity bias of ISAs makes them difficult, and, hence, costly to apply to SME audits (IFAC, 2006).

Clearly, the issue of SME audit is becoming increasingly problematic. The need for audit arises from the need to address the agency problem, as it provides credibility to the financial statements of companies so that external users can rely on these for economic decision-making. With the evolution of businesses, companies have grown and diversified with many seeking cross border listings,

The International Auditing Practices Committee (IAPC) issued its first International Auditing Guideline, Objective and scope of the Audit of Financial Statements in 1979. Since 2002, however, IAPC was reconstituted as the International Auditing and Assurance Standards Board (IAASB). 
and, thus, extending their accountability to the public at large around the world. To these companies, ISAs are very relevant and applicable as they are universally applicable and recognized.

However, there are companies that operate with a family ownership structure with very few external dependent users of the financial statements. In some jurisdictions, including Malaysia, these companies are subject to mandatory audits. Therefore, the issue is whether this is necessary considering their capacity. The trend seems to be shifting towards deregulating the audit requirement for the smaller companies.

\subsection{Development in other Countries}

Australia deregulated its audit requirement as early as 1971 when the Australian Uniform Companies Act 1961 was amended to exempt a small private company from compulsory audit provided that all its shareholders consent thereto. The Companies Act has since been repealed, and, now, under the Corporations Act 2001, a small company is even excused from having to prepare a financial report, and, thus, is exempted from having to appoint an auditor unless, first, it is controlled by a foreign company that has not lodged its consolidated account with the Australian Securities and Investments Commission (ASIC); second, its shareholders, who are holding at least 5 per cent of its voting shares, require it; and, third, the ASIC requires it (section 292 of the Australian Corporations Act 2001). In Singapore, in 2000, the Institute of Certified Public Accountants of Singapore (ICPAS) conducted a survey concerning the issue of audit exemption. The findings indicated that audit exemption was undesirable (ICPAS, 2000). However, despite the findings of the survey, the legislature amended its Companies Act in 2003 to exempt dormant and private companies from audit requirements. The threshold was set at $\mathrm{S} \$ 2.5$ million, and was subsequently increased to $\$ \$ 5$ million in May 2004. As in Australia, shareholders holding at least 5 per cent of the company's issued shares, or the regulator, may require the company's accounts to be audited (section 205B, 205C and 205D of the Singapore's Companies Act).

\subsection{Development in Malaysia}

Malaysia has embarked on a review of the company law. The Company Law Reform Committee was established on 17 December 2003 to reform the company legislation to make it current and in line with the best practices elsewhere (SSM, 2008). One of the steps taken by the Committee was to commission a survey to obtain the views of directors of SMEs on audit exemption. Most of the respondents indicated that they were willing to carry out audits even if the requirement for mandatory audits was removed from the Companies Act 1965. Nevertheless, the Committee, in its Final Report in 2009, recommended the retention of mandatory audit for all companies; however, powers should be given to the regulator to exempt certain types of companies from this requirement. The criteria suggested are based on the number of the company's shareholders, annual turnover, and 
number of employees (SSM, 2009). Thus, the possibility of the mandatory audit regime for small companies being overturned cannot be ruled out. What then is the impact of this on the audit firms?

In Malaysia, due to the limited resources of small private limited companies, those that are not subsidiaries of public listed companies tend to be audited by smaller audit firms, i.e. the SMPs. A survey carried out by the Malaysian Institute of Accountants revealed that out of the total of 1,551 SMPs registered with the Institute as at 29 May 2003, more than 92 per cent were sole proprietors or 2 partner firms. Approximately 66 per cent of the revenue of such firms was dependent on audit service (MIA, 2003). Thus, the issue of audit exemption is especially of interest to the SMPs, because, for them, an exemption regime would mean a reduction in their audit revenue.

\subsection{Past Studies on Audit of Small Firms}

The need to understand the implications of introducing an audit exemption regime was recognized as early as 1982 . Studies have been conducted on the demand for an external audit and the characteristics of companies that favour an external audit. Chow (1982) examined the data of 165 New York Stock Exchange ("NYSE") and over-the-counter ("OTC") companies for the year 1926. In that year, there was no externally imposed audit requirement. Chow found only moderate support for the hypothesis that the larger the company's total size, the higher the probability that the company voluntarily engages in external auditing. Due to the lack of data, the correlation between manager ownership and voluntary audit was not examined. However, in subsequent studies in other jurisdictions, the correlation between the demand for voluntary audit and manager ownership was examined. Senkow et al. (2001) surveyed 896 Canadian companies that were given the opportunity to discontinue audit and found that the correlation of the two variables was not significant. However, studies conducted by Carey et al. (2000) on Australian family businesses, and by Tabone and Baldacchino (2003) on owner-manager companies in Malta found that the demand for voluntary audit is positively correlated with the proportion of non-family management. The earlier surveys (Collis et al., 2004; Seouw, 2001; Tauringana and Clarke, 2000) showed consistency with the theory that the demand for auditing is correlated to a greater loss of control by the owners, which leads to a demand for monitoring.

Another characteristic of a company that will opt for audit if it is given an option is that its directors have knowledge of the benefits of audit (Collis et al., 2004). Thus, it follows that companies that find audit to be beneficial are more likely to retain audit after its deregulation (Senkow et al., 2001; Collis, 2008). Audit acts as a check on internal controls (Collis et al., 2004), on accounting systems and controls (Collis, 2008); and it increases the quality of information (Collis et al., 2004; Tabone and Baldacchino, 2003). In addition, Tabone and Baldacchino (2003) found that the external audit imposes discipline on the ownermanager and staff to avoid errors and other irregularities. 
Surprisingly, Seouw (2001) found that factors, such as the strength and quality of the working relationship between the company and its auditors, do not play a significant role in the company's decision concerning whether to opt for voluntary audit. Instead, there is evidence that the company may consider the cost factor when deciding whether to go for audit if given the choice. Costs include monetary and management time spent in carrying out the audit.

In Malaysia, Salleh et al. (2008) surveyed the opinions of the SMPs' concerning the audit of small companies and the proportion of its contribution to their revenue. Approximately 76.6 per cent of the SMPs are of the view that all companies, irrespective of size, should be subject to mandatory annual audits. As expected, the majority of these SMPs are small firms (68.8 per cent) that rely heavily on audit as the major contribution to their income (59.4 per cent). Their fear of losing this source of income may be the reason for polling against the deregulation of audit for small businesses. This is the only previous study conducted in Malaysia that examines the issue of voluntary audit (Chan, 2012).

According to the survey commissioned by the Corporate Law Reform Committee on the directors of private limited companies, 71 per cent of the respondents say that they will carry out audits even if the requirement for mandatory audits is removed from the Companies Act 1965. Approximately 82 per cent of them found audit to be beneficial as it provides assurance to its creditors, and improves its record keeping and internal control (CLRC, 2007). Unfortunately, the study, which was conducted in early 2005, the results of which were released in February 2006, did not analyse the ownership characteristics of such companies.

Thus, this study was conducted after the commencement of the abovementioned survey commissioned by the Corporate Law Reform Committee, to determine whether there is a significant difference between the ownership structure of SMEs and their opting for voluntary audit when it is no longer a matter of obligation. The results will be beneficial to both practitioners and regulators by assisting them in taking the correct path either towards making SME audit voluntary or retaining it as a legal obligation.

\subsection{Theoretical Model}

Based on the above review of the literature, two main variables have been identified that are hypothesized to be critical in opting for voluntary audit. Figure 1 shows the theoretical model developed as a starting point for the exploratory phase of the research.

This model links the ownership structure of SMEs and their resources for making the choice for a voluntary audit, which are explained as follows:

Ownership structure has been discussed as an independent variable in relation to SME audit in several studies (see Collis, 2008; Collis et al., 2004; Collis, 2003). Furthermore, Anderson et al. (2003) looked into the founding family ownership in respect of its lenders. In addition, the correlation between the 


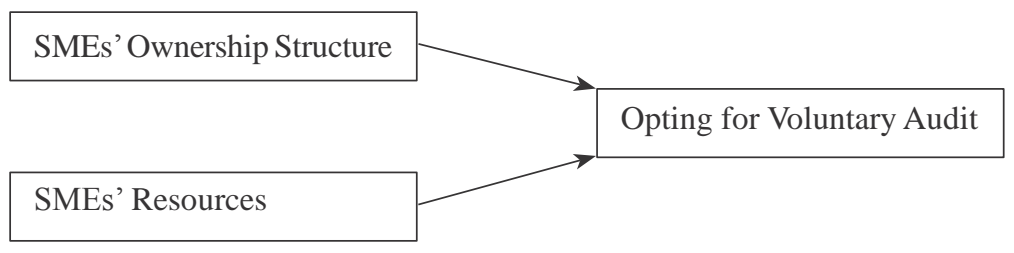

Figure 1: Influencing Factors on SMEs' Voluntary Audit

demand for voluntary audit and manager ownership was examined. In Canada, Senkow et al. (2001) did not find a significant relationship between managerial ownership and voluntary audit. However, Carey et al. (2000), in their study on Australian family businesses, found a positive association between the proportion of non-family management and demand for voluntary audit. Similarly, Tabone and Baldacchino (2003) found that for owner-managed companies in Malta, the demand for voluntary audit was positively correlated with the proportion of nonfamily management. Hence, there is support in the literature (Collis et al., 2004; Seouw, 2001; Tauringana and Clarke, 2000) that the demand for auditing is correlated to a greater loss of control by the owners, which, thus, leads to demand for audit.

In this study, we classify the ownership structure into three categories; namely, wholly family-owned (WF), partly family-owned (PF), and non-family owned (NF). Non-family owned includes unrelated shareholders. This variable is strongly rooted in the agency theory (Jensen and Meckling, 1976), which asserts that the demand for audited financial statements arises from information asymmetry on the premise that human nature is weak, untrustworthy and in need of some kind of checking (Power, 1997).

Based on the above discussion, we hypothesise that:

$\mathrm{H}_{1}$ : There are significant differences between the different modes of ownership structure (wholly family-owned, partly family-owned, and non-family owned) and SMEs opting for voluntary audit.

Interestingly, in a subsequent study by Collis (2008) on medium sized companies in the UK that do not enjoy audit exemption, 73 per cent of the responding firms that were closely held, indicated that they would continue to have their accounts audited even if the exemption was extended to them. Given that, generally, the agency rationale is applied to large firms, the evidence from Collis (2008) suggests that there may be other factors that may lead to the willingness of SMEs for audit. We identify SME resources as one of the factors.

SMEs' resources include tangible and intangible, and human and nonhuman resources that are possessed or controlled by the firm. Based on the 
'resource dependency theory', limitations on the availability of resources foster specialization and necessitate organizational interdependence, thus, creating resource dependencies (Ulrich and Barney 1984; Cook and Emerson 1984; Pfeffer 1981; Pfeffer and Salancik 1978; Cook 1977). Therefore, as SMEs may be crippled by the "capacity problem" or a lack of resources, such as qualified accountants, business expertise, right mechanisms, as noted by IFAC (2006), would seek for the obvious benefits derived from the audit process. In doing so, they would be able to compensate for their lack of resources, and, therefore, the benefits gained would outweigh the cost incurred via audit. Evidence from Iranian SMEs shows that resource dependency is a significant factor to motivate SMEs to outsource their accounting functions (Kamyabi and Devi, 2011). Therefore, based on this resource-dependency rationale for audit, we can link the resources of SMEs' to opting for voluntary audit. We hypothesise that:

\section{$\mathrm{H}_{2}$ : Lack of SMEs' resources is significantly related to opting for voluntary audit.}

\section{Methodology}

This study is exploratory and descriptive in nature. The data collection method employed is a questionnaire survey targeting SMEs registered with the Small and Medium Industries Development Corporation (SMIDC) in Malaysia. The full directory list of SMEs registered with the SMIDEC was obtained online, and, as at 23 February 2005, the number of registered SMEs located in Selangor and Kuala Lumpur, Federal Territory, totalled 4,838 companies, and formed the population of this study (SMIDEC, 2005). Out of this population, 235 companies, which represent both manufacturing and service sectors, were randomly selected. To name a few, manufacturing companies, such as chemical petrochemical products (71 companies); electrical and electronics including telecommunication (1,294 companies); machinery and engineering (769 companies); metal products (872 companies); transport equipment (658 companies); wood and wood products (41 companies); food, beverages and tobacco (88 companies); and service firms, such as professional management services (31 companies); retail and wholesale distributive trade (10 companies ); logistics (2 companies); IT services (1 company); and hospitality services (1 company), were available within the population directory, and in the sampled population accordingly.

In 2005, the National SME Development Council (NSDC) approved the use of common definitions for SMEs in the manufacturing, manufacturing-related services, primary agriculture and services sectors. ${ }^{3}$ These definitions are applied by all Government Ministries and Agencies involved in SME development, as well

\footnotetext{
Classification of economic activities is based on the Malaysian Standard Industrial Classification (MSIC) 2000 codes.
} 
as by the financial institutions (SMEinfo, 2010). Malaysian SMEs are classified into three main categories: micro, small or medium. These groupings are decided based on either the number of people a business employs, or on the total sales or revenue generated by a business in a year. According to Wignaraja (2003), different criteria can be used to distinguish between an SME and a large firm in a developing economy. Three possible criteria are the number of employees, the value of sales and the value of production equipment. In this study, as the determinants of firm classification, the number of full-time employees in all national business sites as well as annual sales turnover, have been considered. Tables 1 and 2 show the classification of the SMEs based on the number of fulltime employees and annual sales turnover.

Table 1: Number of Employees

\begin{tabular}{|l|l|l|l|}
\hline \multicolumn{1}{|c|}{$\begin{array}{c}\text { Primary } \\
\text { Agriculture }\end{array}$} & \multicolumn{1}{|c|}{$\begin{array}{c}\text { Manufacturing } \\
\text { (including } \\
\text { Agro-Based) \& MRS* }\end{array}$} & $\begin{array}{c}\text { Services Sector } \\
\text { (including ICT**) }\end{array}$ \\
\hline Micro & $\begin{array}{l}\text { Less than 5 } \\
\text { employees }\end{array}$ & Less than 5 employees & $\begin{array}{l}\text { Less than 5 } \\
\text { employees }\end{array}$ \\
\hline Small & $\begin{array}{l}\text { Between 5 \& 19 } \\
\text { employees }\end{array}$ & $\begin{array}{l}\text { Between 5 \& 50 } \\
\text { employees }\end{array}$ & $\begin{array}{l}\text { Between 5 \& 19 } \\
\text { employees }\end{array}$ \\
\hline Medium & $\begin{array}{l}\text { Between 20 \& 50 } \\
\text { employees }\end{array}$ & $\begin{array}{l}\text { Between 51 \& 150 } \\
\text { employees }\end{array}$ & $\begin{array}{l}\text { Between 20 \& 50 } \\
\text { employees }\end{array}$ \\
\hline
\end{tabular}

*MRS: Manufacturing-Related Services

** ICT: Information and Communications Technology

Source: SMEinfo, 2010

Table 2: Annual Sales Turnover

\begin{tabular}{|l|l|l|l|}
\hline Primary Agriculture & $\begin{array}{l}\text { Manufacturing } \\
\text { (including Agro- } \\
\text { Based) \& MRS* }\end{array}$ & \multicolumn{1}{|c|}{$\begin{array}{c}\text { Services Sector } \\
\text { (including ICT**) }\end{array}$} \\
\hline Micro & Less than RM200,000 & Less than RM250,000 & Less than RM200,000 \\
\hline Small & $\begin{array}{l}\text { Between RM200,000 } \\
\text { \& less than RM1 } \\
\text { million }\end{array}$ & $\begin{array}{l}\text { Between RM250,000 } \\
\text { \& less than RM10 } \\
\text { million }\end{array}$ & $\begin{array}{l}\text { Between RM200,000 } \\
\text { \& less than RM1 } \\
\text { million }\end{array}$ \\
\hline Medium & $\begin{array}{l}\text { Between RM1 million } \\
\text { \& RM5 million }\end{array}$ & $\begin{array}{l}\text { Between RM10 } \\
\text { million \& RM25 } \\
\text { million }\end{array}$ & $\begin{array}{l}\text { Between RM1 million } \\
\text { \& RM5 million }\end{array}$ \\
\hline
\end{tabular}

*MRS: Manufacturing-Related Services

** ICT: Information and Communications Technology

Source: SMEinfo, 2010 
Based on the above classification and with the assistance of the SME directory, 235 questionnaires were sent through email, fax and by hand delivery to the managing director or chief financial officer of the respective firms. It is believed that these managers are better able to provide a more rational opinion on the subject of audit as they would know how the introduction of voluntary audit could impact them. The questionnaires were also accompanied by letters of appreciation and instructions. The cover letter informed respondents of the aims of the project and the main benefits of undertaking such a study. It also informed participants about the issues of privacy relating to sensitive business information. After two to three days, follow up telephone calls were made to encourage them to respond. Finally, a total of 200 usable responses were obtained, representing a response rate of 85 per cent.

The questionnaire used in this study is mainly based on a questionnaire used by the Institute of Certified Public Accountants of Singapore (ICPAS) in December 2000, as well as the study on Directors Views on Exemption from Statutory Audit conducted by Collis in the UK in 2003. There are 30 questions in the questionnaire. Questions 1 to 7 are designed to elicit the respondent's demographic and profile, and questions 30 and 31 concern the position of the respondent in the company and his qualification. The questionnaire also includes questions on the role of the external accountant (question 8) and the option to be an exempt enterprise for the purpose of financial reporting (questions 9 to 11). Overall, the rest of the questionnaire concerns the cost of audit and views on the introduction of audit exemption for small and medium sized-enterprises in Malaysia.

\section{Results and Discussion}

To obtain descriptive statistics for categorical variables, frequencies and percentages are employed. To test the hypotheses of this study, an independentsamples t-test is used. In what follows, the results are presented.

\subsection{Descriptive Analysis - Responding SMEs}

An analysis of the ownership structure of SMEs shows that the majority of SMEs have non-related shareholders or are non-family owned (82 out of 200 or 41 per cent); 66 SMEs are partly-family owned (33 per cent); and 52 are wholly family-owned (26 per cent).

The analysis of the number of accountants in the SMEs who are employed in a financial role reveals that 96 out of the 200 SMEs have only one accountant (48 per cent); 8 SMEs have only two accountants (4 per cent) and 96 SMEs do not have any employee as an accountant (48 per cent).

The analysis of the qualification level of the accountants employed by the SMEs in descending order show that only 7 SMEs have "professionally qualified accountants holding Certified Public Accountants (CPA)/Charted Accountants 
(CA)/Association of Chartered Certified Accountants (ACCA)' (6.3 per cent); 40 have 'non-CPA degree holders registered with the Malaysian Institute of Accountants MIA'4 (35.7 per cent); 43 have 'semi-professional accountants who have partially completed their professional examinations' (38.4 per cent); and 22 have 'accounting technicians with London Chamber of Commercial Industry (LCCI)/Association of Accounting Technician (AAT) qualification or bookkeepers' (19.6 per cent).

The analysis of the number of shareholders of SMEs show that the majority of the responding SMEs have three to four shareholders (158 out of 200 or 79 per cent); 32 have five or more shareholders (15.6 per cent); and 10 SMEs have one to two shareholders (5 per cent).

Lastly, the SMEs' perceptions/views of the potential value of the audit were measured on a five-point Likert-type scale by eight items that were designed to elicit responses ranging from strongly agree to strongly disagree (allowing multiple responses). The results, in descending order, show that, first, they mainly use 'audit' as a check on accounting records and systems (198 out of 200, or 99 per cent, ticked strongly agree or agree); second, they acknowledge the value of audit as it 'helps protect against fraud' (171 out of 200, or 85.5 per cent); third, 'audit improves the credibility of the financial information' (170 out of 200, or 85.0 per cent); fourth, 'audit improves the quality of the financial information' ( 169 out of 200 , or 84.5 per cent); fifth, 'audit provides assurance to shareholders' ( 169 out of 200 , or 84.5 per cent); sixth, 'audit provides assurance to the bank and other lenders' (156 out of 200, or 78.0 per cent); seventh, 'it has a positive effect on company's credit rating score' (151 out of 200, or 75.5 per cent), and, finally, 'it provides assurance to suppliers and trade creditors' (151 out of 200 , or 74.0 per cent). The views of the respondents on voluntary audit are important because previous studies have shown that companies that find audit beneficial are more likely to retain audit after its deregulation (Senkow et al., 2001; Collis, 2008). Since this study is partly based on the previous studies, but in a new context, it is more reliable to have at least a similar grounding concerning the perspective of SMEs in relation to voluntary audit. However, the following results show that some of the conclusions made in studies conducted in other contexts do not apply to Malaysia.

\footnotetext{
Under the Accountants Act 1967 and subsequent amendments, holders of seven local universities' accounting degrees and members of 11 professional bodies are eligible to directly become members of the MIA. The bodies are: MACPA, Institute of Chartered Accountants in England \& Wales, Institute of Chartered Scotland, Institute of Chartered Accountants in Ireland, Institute of Chartered Accountants in Australia, CPA Australia (successor to the Australian Society of Accountants), Chartered Institute of Management Accountants, Association of Chartered Certified Accountants, Canadian Institute of Chartered Accountants, New Zealand Institute of Chartered Accountants (successor to the New Zealand Society of Accountants) and Institute of Chartered Accountants in India. Since 2001, members of foreign professional bodies and graduates with degrees not recognized in the Act have been required to undergo the Qualifying Examination. The inclusion of holders of local accounting graduates dates back to the 1970s. (See www. mia.org.my)
} 


\subsection{Testing Hypothesis 1: Ownership Structure}

To examine if there is a significant difference between ownership structure and SMEs' opting for voluntary audit, the t-test was used. As noted earlier under descriptive analysis, the majority of the respondents (41 per cent) have non-related shareholders or are non-family owned. Partly family-owned SMEs constitute 33 per cent, and 26 per cent are wholly family-owned SMEs. Table 3 provides the results of the analysis.

Table 3: Ownership Structure versus Voluntary Audit Decision

\begin{tabular}{|l|c|c|c|c|c|c|c|c|l|}
\hline Characteristic & $\begin{array}{c}\text { Strg } \\
\text { Agree } \\
\underline{5}\end{array}$ & $\begin{array}{c}\text { Agree } \\
\underline{4}\end{array}$ & $\begin{array}{c}\text { Not } \\
\text { Sure } \\
\underline{3}\end{array}$ & $\begin{array}{c}\text { Dis- } \\
\text { agree } \\
\underline{2}\end{array}$ & $\begin{array}{c}\text { Strg } \\
\text { Disag } \\
\underline{1}\end{array}$ & Mean & t-test & $\begin{array}{c}P \\
\text { value }\end{array}$ & \\
\hline Ownership & 27.45 & 31.37 & 21.57 & 9.80 & 9.80 & 3.5686 & $3.2^{* * *}$ & 0.0012 & $\mathrm{WF}$ \\
Structure & 17.19 & 31.25 & 31.25 & 9.38 & 10.94 & 3.3438 & $2.3 * *$ & 0.0125 & $\mathrm{PF}$ \\
& 10.84 & 13.25 & 48.19 & 20.48 & 7.23 & 3.0000 & 0.0000 & 0.5000 & $\mathrm{NF}$ \\
& 17.17 & 23.74 & 35.86 & 14.14 & 9.09 & 3.2576 & $3.1 * * *$ & 0.0011 & All \\
\hline
\end{tabular}

Notes: 1)N = 198 (based on usable responses); 2) WF = Wholly Family-Owned, PF = Partly-Family Owned, and NF = Non-Family Owned (unrelated shareholders); 3 ) $* * *$ significant at 0.001 ,

** significant at 0.05 ,

According to Table 3, based on the analysis of the mean scores of the respective categories and the t-test conducted, it is noted that partly familyowned SMEs favour voluntary audit at a .05 significance level, whereas wholly family-owned SMEs strongly prefer voluntary audit at the .001 significance level. Overall, both family-related ownership structures opt for voluntary audit, while, in contrast, non-family owned SMEs seem to be not keen to opt for voluntary audit, or are mainly undecided. This finding is in contrast to the results of the Collis et al. (2004) survey, in which it was concluded that non-family owned companies would be more likely to prefer voluntary audit, where it is believed that a higher level of owner/family management would result in less desire for audit due to the access and availability of the financial information to these parties.

Based on the above, it would be logical to accept the first hypothesis of this study, which holds that 'there are significant differences between different modes of ownership structure (wholly family-owned, partly family-owned, and non-family owned) and SMEs'opting for voluntary audit'.

\subsection{Testing Hypothesis 2: Resources}

However, the results for hypothesis 1 do not fully corroborate the 'agency theory', which is more relevant and applicable in a complex set-up in which the directors have only a minor stake in the company, and, thus, may work towards maximizing their personal gains instead of those of the shareholders. In addition, the majority 
of the firms in our sample (79 per cent) have only three to four shareholders. Therefore, other factors seem to be involved, which influence the firms' decision to opt for voluntary audit. This conflict forms the basis for the second hypothesis of this study, which states that a 'Lack of SMEs' resources is significantly related to opting for voluntary audit'.

In view of the second hypothesis, three sub-dimensions: 'level of services received by SMEs' (Service), 'reliance on external accountants' advice (advice), and 'the value derived from the audit' (value) have been chosen for further analysis (Kamyabi and Devi, 2011). Table 4, Table 5, and Table 6 show the results.

Table 4: Comparison Level of Services vs. Ownership

\begin{tabular}{|c|c|c|c|c|c|}
\hline Ownership & $\begin{array}{c}\text { Services } \\
\text { Class }\end{array}$ & Mean & $\begin{array}{c}\text { Service } \\
\text { Mean }\end{array}$ & t-value & p-value \\
\hline \multirow{3}{*}{ NF } & $\begin{array}{c}\text { None } \\
1 \text { to } 4\end{array}$ & $\begin{array}{c}3.0294 \\
3.3333\end{array}$ & & & \\
& 5 to 7 & 2.9310 & 3.5062 & -1.1900 & 0.1184 \\
& 8 to 10 & 2.7778 & & & \\
\hline \multirow{3}{*}{ PF } & None & 3.6800 & & & \\
& 1 to 4 & 2.6667 & 4.1846 & $-4.04 * * *$ & 0.0000 \\
& 5 to 7 & 3.1600 & & & \\
\hline \multirow{3}{*}{ WF } & 8 to 10 & 2.7778 & & & \\
& None & 3.7500 & & & \\
& 1 to 4 & 4.0000 & 5.5700 & $-2.56 * * *$ & 0.0058 \\
& 5 to 7 & 3.3333 & & & \\
\hline
\end{tabular}

Notes: 1) $\mathrm{N}=198$. 2) $\mathrm{None}=$ no additional services received, 1 to $4=$ 1 to 4 types of services received, 5 to $7=5$ to 7 types of services received, 8 to $10=8$ to 10 types of services received

Table 4 summarizes the results of the analysis of the SMEs decision concerning voluntary audit by mapping the mean voluntary audit decision response for different levels of service received according to the different ownership categories.

The results show that wholly family-owned SMEs have the highest mean scores on services compared to partly family-owned and non-family owned SMEs. The results are very significant at the .001 level for both partly and wholly family-owned SMEs. At this significance level, partly and wholly family-owned SMEs strongly favour outsourcing services. Obviously, non-family owned SMEs do less outsourcing to auditors in comparison to partly and wholly-family owned SMEs. This could be the result of non-family owned SMEs having more accounting capability compared to the other two types of ownership. In 
fact, the resource dependency theory emphasizes the power that underpins the outsourcing relationship. In view of the results, this possibility of a higher level of dependency by wholly and partly family-owned SMEs on the external accountant for accounting services could be rooted in their lack of accounting resources be it human resources in the form of (qualified) accountants or intangible resources as accounting expertise.

In view of the second sub-dimension, reliance on external accountant's advice, on a scale of 1 to 5 where $1=$ strongly disagree and $5=$ strongly agree, the sampled SMEs were asked to indicate whether audit was conducted to seek the accountant's advice. For each respective ownership category, the mean score for voluntary audit at each level of advice response is computed, and a t-test conducted. Table 5 summarizes the results.

According to Table 5, there is a strong preference for voluntary audit in the partly family-owned and wholly family-owned SMEs when the level of reliance on external accountant advice is high at a significance level of .01 and .05 , respectively. This further supports that family-owned businesses are heavily dependent on the external accountant's advice. Additionally, these results corroborate the previous findings that this reliance may be due to the outsourcing of accounting requirements, and, thus, support their need for voluntary audit as a readily available source of accounting expertise (Keasey et al., 1988).

Table 5: Reliance on External Accountants Advice vs. Voluntary Audit and Ownership

\begin{tabular}{|c|c|c|c|c|}
\hline Ownership & $\begin{array}{l}\text { Reliance } \\
\text { Advice }\end{array}$ & $\begin{array}{c}\text { Voluntary Audit } \\
\text { Mean }\end{array}$ & t-value & $P$ value \\
\hline NF & $\begin{array}{l}\text { Strg Dsg } \\
\text { Dsg } \\
\text { Undec } \\
\text { Agree } \\
\text { S Agree }\end{array}$ & $\begin{array}{l}4.0000 \\
\text { na } \\
3.0000 \\
2.8108 \\
3.0357\end{array}$ & $\begin{array}{l}2.7400 \\
0.7000 \\
-1.3100 \\
0.1700\end{array}$ & $\begin{array}{l}0.0204 \\
0.5000 \\
0.0988 \\
0.4327\end{array}$ \\
\hline PF & $\begin{array}{l}\text { Strg Dsg } \\
\text { Dsg } \\
\text { Undec } \\
\text { Agree } \\
\text { S Agree }\end{array}$ & $\begin{array}{l}2.6667 \\
3.6000 \\
3.1111 \\
3.3158 \\
3.6500\end{array}$ & $\begin{array}{l}-0.5000 \\
0.8800 \\
0.3300 \\
1.1000 \\
3.5800 * * *\end{array}$ & $\begin{array}{l}0.3333 \\
0.2132 \\
0.3711 \\
0.1426 \\
0.0010\end{array}$ \\
\hline WF & $\begin{array}{l}\text { Strg Dsg } \\
\text { Dsg } \\
\text { Undec } \\
\text { Agree } \\
\text { S Agree }\end{array}$ & $\begin{array}{l}3.3333 \\
4.5000 \\
3.6667 \\
3.3333 \\
3.5714\end{array}$ & $\begin{array}{l}1.0000 \\
1.8400 \\
1.7300 \\
0.9700 \\
2.2800 * *\end{array}$ & $\begin{array}{l}0.2113 \\
0.2230 \\
0.0532 \\
0.1724 \\
0.0200\end{array}$ \\
\hline
\end{tabular}

Notes: 1) $\mathrm{N}=198$; 2) Strg Dsg = Strongly Disagree, Dsg = Disagree,

Undec $=$ Undecided, $\mathrm{S}$ Agree $=$ Strongly Agree 
Table 6: Value of Audit vs. Voluntary Audit Decision and Level of Family Ownership

\begin{tabular}{|c|l|c|l|l|}
\hline Ownership & Value & Mean & t-value & $P$ value \\
\hline \multirow{2}{*}{ NF } & Hi & 3.1900 & 1.3700 & 0.0880 \\
& Mod & 2.6400 & $-1.84^{* *}$ & 0.0383 \\
\hline \multirow{2}{*}{ PF } & Hi & 3.5900 & $3.59 * * *$ & 0.0004 \\
& Mod & 2.6300 & 2.1700 & 0.9838 \\
\hline \multirow{2}{*}{ WF } & Hi & 3.5000 & $2.45^{* * *}$ & 0.0093 \\
& Mod & 3.7500 & $3^{* * *}$ & 0.0100 \\
\hline
\end{tabular}

Notes: 1) $\mathrm{N}=198$; 2) $\mathrm{Hi}=$ High average value score

4 to 5 . Mod=Moderate average value score 3 to 4 .

Low (less than 3 ) average score, which was not found

Table 6 shows the results of the voluntary audit responses for the SMEs classified as having high and moderate value from the audit, mapped to the respective ownership category. Based on the results, most of the wholly familyowned SMEs perceive the value of audit as either high or moderate. In addition, there is a significant relationship between the perceived value of the audit (both high and moderate), and opting for voluntary audit. This being significant at the 1 per cent level shows their strong preference for voluntary audit.

Partly family-owned SMEs also perceive the value of audit as either high or moderate, yet those who perceive the value of audit as high tend to significantly opt for voluntary audit. This relationship is extremely significant (sig. at .0001) and shows their high level of preference for voluntary audit.

As for non-family owned SMEs, it can be seen that they also perceive the value of audit as either high or moderate. However, there is a significant relationship between value of audit and opting for voluntary audit only among those SMEs that perceive the value as moderate. The significance level here is $p<.05$, which shows a weaker state of preference for voluntary audit.

Overall, only wholly family-owned SMEs have both high and moderate audit value perceptions significantly related to voluntary audit, which shows that this strong preference may not be eliminated by providing them with a choice. This, however, may possibly be due to the influence of the external accountant on the respondents' perceptions concerning the benefits of the audit (Collis et al., 2004). This is consistent with the earlier analysis, which finds that family-owned SMEs rely heavily on the external accountant's advice.

In sum, it can be seen that dimensions, such as service, advice, and value, which represent the lack of resources of the sampled SMEs, are significantly related to their opting for voluntary audit, albeit not in absolute ways. Therefore, the second hypothesis is accepted as holding true concerning this sample. 


\section{Conclusion}

Based on the above findings it can be concluded that, overall, both family-related ownership structures opt for voluntary audit, while, in contrast, non-family owned SMEs seem to not be keen on opting for voluntary audit or are mainly undecided. This shows their strong preference for voluntary audit and their lack of motivation to comply with a would-be voluntary regime. These findings lead to the acceptance of the first hypothesis of the study, which holds that 'there are significant differences between different modes of ownership structure (wholly family-owned, partly family-owned, and non-family owned) and SMEs opting for voluntary audit'. However, as the results do not fully corroborate the 'agency theory' and are in conflict with the findings of Collis et al. (2004), further analysis has been based on the resource dependency theory (RDT).

In view of the level of services and reliance of advice, it can be concluded that, predominantly, family-owned SMEs (both wholly family- and partly familyowned) tend to outsource their accounting services to audit firms. In fact, they are heavily dependent on the auditing services to increase the confidence, quality, credibility, and assurance of their financial information. This reliance may be due to the outsourcing of accounting requirements, and, thus, support their need for voluntary audit as a readily available source of accounting expertise (Keasey et al., 1988). Yet, as far as the perceived value from auditing is concerned, almost all SMEs view audit value as either high or moderate. However, mostly, SMEs with a family structure have a strong preference for voluntary audit when the perceived value is high.

In short, in the case of Malaysian SMEs, it seems that, possibly, a higher level of dependency by wholly and partly family-owned SMEs on the external accountant for accounting services could be rooted in their lack of accounting resources be it human resources in the form of (qualified) accountants or intangible resources as accounting expertise. In fact, the resource dependency theory emphasizes the power, which underpins the outsourcing relationship. Therefore, it would be the case here that the resource dependency theory could provide a better explanation for the tendency of Malaysian family-owned SMEs to opt for voluntary audit. Their preference for audit is mainly due to their lack of resources as compared to SMEs with non-family related ownership. Thus, the second hypothesis of the study, which holds that a 'Lack of SMEs' resources is significantly related to opting for voluntary audit', is supported. These conclusions also lead us to several practical implications.

First, this research provides empirical evidence for audit policy makers so that they can make a more plausible decision concerning the audit exemption regime. This research shows that firms that perceive benefits from audit have indicated that they will opt for voluntary audit. This may spur SMPs to be more innovative and offer more value added services. These findings can be of value to other countries, which are experiencing the same undecided or pending situation. 
Second, the results spotlight a lack in the number of qualified accountants in Malaysia as an emerging economy, therefore, education bodies and curriculum designers should deliberate over the gap between demand and supply and formulate a pragmatic solution to close this gap.

Third, if SME audit becomes optional and SMEs become independent, a large number of SMPs will suffer from a huge revenue cut, which, in turn, will lead to other issues, such as downsizing, filing for bankruptcy, and dissatisfaction. Alternatively, auditors will be compelled to provide genuine value added services to remain competitive. Consequently, the businesses that perceive benefits will continue to seek out external accountants. Thus, we concur with Chan (2012) that it is timely for auditors to review their role to ensure that audit remains relevant and continues to be a vital link in the financial reporting value chain. We believe that there should be a demand for audit even by companies that are exempted from the requirement. The small audit firms that produce quality audit work should be able to survive.

This research also opens new avenues for further research to focus more deeply on the ownership structure of Malaysian SMEs. This can be done through conducting large-scale studies, which are of more confirmatory value and their results more generalizable. Indeed, the decision to introduce audit exemption requires further detailed studies concerning the consequences of and implications for the national economy. In addition, the decision has to be made after careful consideration and consultation with all stakeholders. Therefore, triangulation among SMEs, SMPS, policy makers and other stakeholders is necessary.

In conclusion, in answer to the question: "does ownership matter?", it does, because, in the context of an emerging economy like Malaysia, smaller family owned companies lack the necessary resources and look towards audit to provide assurance to the owners themselves.

\section{References}

Abdel-Khalik, A.R. (1993). 'Why Do Private Companies Demand Auditing? A Case for Organizational Loss of Control'. Journal of Accounting, Auditing and Finance, vol. 8, no. 1, pp. 31-52.

Abdul Aziz, N.A. (2002), 'Audit Exemption for Private Limited Companies', Akauntan Nasional, April , pp. 52-54.

Arens, A.A., Loebecke, J.K., Iskandar, T.M., Susela, S.D., and Isa, S. (1999), Auditing in Malaysia: An Integrated Approach, Petaling Jaya: Malaysia, Prentice Hall.

Barfield, R. M., J. J. Gaver, and T. O’Keefe. (1993), 'Additional evidence on the economics of attest. Extending results from the audit market for compilations and reviews', Auditing: A Journal of Theory of Practice, vol. 12, no.1, pp. 74-87. 
Barney, J. B. (1991), 'Firm Resources and Sustained Competitive Advantage', Journal of Management, vol. 17, no.1, pp. 99-120

Carey, P., Simnett R. and Taneewski, G. (2000). 'Voluntary Demand for Internal and external Auditing by Family Businesses'. Auditing: A Journal of Practice \& Theory, vol.19, pp. 37-51.

Carey, P.(2010), The Benefit Small and Medium Sized Enterprises Derive from External Audit, Working Paper, Monash University, Australia.

Chan, W.M. (2012). 'Exemption of Annual Audit for Small Companies: A Review', Pertanika Journal of Social Science and Humanities, 20(1), pp1-10.

Cook, K. S. (1977), 'Exchange and power in networks of interorganizational relations', Sociological Quarterly, vol.18, no.1, pp. 62-82.

Cook, K. S., \& Emerson, R. (1984), 'Exchange networks and the analysis of complex organizations. Sociology of Organizations', vol. 3, pp. 1-3

Chow, C.W. (1982). 'The Demand for External Auditing: Size, Debt and Ownership Influences', Accounting Review vol.57, no. 2, pp. 272-291.

Collis, J, Jarvis, R and Skerratt, L. (2004). 'The Demand for the Audit in Small Companies in the UK', Accounting and Business Research,vol. 34, no.2, pp.87-100.

Collis, J. (2003). 'Directors' Views on Exemption from the Statutory Audit' - A Research report for the DTI, Retrieved Nov. 19, 2003, from http://www. dti.gov.uk/collis_rep.pdf.

Collis, J. (2008). 'Directors' Views on Accounting and Auditing Requirements for SMEs', Department for Business Enterprise \& Regulatory Reform UK.

Corporate Law Reform Committee (2007), 'A Consultative Document Creating a Conductive Legal and Regulatory Framework for Business’. January 2007.

Fogarty, T. J., V. S. Radcliffe, and D. R. Campbell. (2006), 'Accountancy before the fall. The AICPA vision project and related professional enterprises', Accounting Organizations and Society, vol.31, pp. 1-25.

Greenwood, R., R. Suddaby, and C. R. Hinings. (2002), 'Theorizing change: The role of professional associations in the transformation of institutional fields', Academy of Management Journal, vol. 45, no.1, pp. 58-80.

IFAC (2004). Challenges and Successes in implementing International Standards: Issues relating to Convergence to IFRSs and ISAs. International Federation of Accountants.

IFAC (2006). SME-Audit - Views of IFAC Small and Medium Practices Committee. Presented by Deputy Chair Lino de Vecchi at the FEE/AMA SME/SMP Versailles Congress on "Growing Businesses in a changing global environment”, Plenary session on SME audit, 7 September 2006.

Institute of Certified Public Accountants of Singapore (ICPAS), (2000), Submission of Audit Exemption for Private Limited Companies Incorporating Findings and Analysis of Survey Results, ICPAS.

Jensen, M.C. and Meckling, W.H. (1976), 'Theory of the Firm: Managerial Behavior, Agency Costs and Ownership Structure', Journal of Financial and Economics, vol.3, pp. 281. 
Keasey, K., Watson, R. and Wynarczyk, P. (1988), 'The Small Company Audit Qualification: A Preliminary Investigation', Accounting and Business Research, vol.18, pp. 323-333.

Kamyabi, Y. \& Devi,S. (2011). Use of Professional Accountants' Advisory Services and Its Impact on SME Performance in an Emerging Economy: A Resource- Based View. Journal of Management and Sustainability, Vol. 1, No.1, September. Canadian Center of Science and Education.

Malaysian Institute of Accountants (MIA)(2003), 'Globalization and Liberalization of Trade in Services: Challenges and Direction for the Malaysian Accountancy Services Sector'.

$\mathrm{Ng}$, D. S. (1978), 'An information economics analysis of financial reporting and external audit', The Accounting Review, (October), pp.910-920.

Penrose, E.T., (1959), The Theory of the Growth of the Firm, Wiley, New York, NY. Pfeffer, J. (1981), Power in Organizations., Marshfield MA: Pitman.

Pfeffer, J., \& Salancik, G. ,(1978), The external control of organisations: A resource dependence

perspective. New York: Harper \& Row.

Salleh, A., Rose, R.C., Kumar, N. and Jaafar, S. (2008), 'Auditors' Perceptions on Obliteration of Mandatory Annual Audit: An Empirical Study’ International Research Journal of Finance and Economics, vol.14, pp. 61-67.

Senkow, D.W., Rennie. M.D., Rennie, R.D. and Wong, J.W. (2001), 'The Audit Retention Decision in the Face of Deregulation: Evidence from Large Private Canadian Corporations', Auditing, vol. 20, no.2, pp. 101-113.

Seouw, J.L. (2001), 'The Demand for the UK Small Company Audit - An Agency Perspective', International Small Business Journal, vol.19, no.2, pp. 61- 79.

Sikka, P., Filling, S. and Liew, P. (2009), 'The Audit Crunch: Reforming Auditing', Managerial Auditing Journal, vol. 24, no.2, pp. 135-155.

SMEinfo, viewed 29 Jan, (2010),http://www.smeinfo.com.my/index. $\mathrm{php}$ ?ch=2\&pg=1\&ac=4\&lang=\#4

Spanos, Y.E., Lioukas, S., (2001). An examination into the causal logic of rent generation: contrasting Porter's competitive strategy framework and the resource-based perspective. Strategic Management Journal 22 (10),907-934.

Suruhanjaya Syarikat Malaysia (SSM) (2008), 'Corporate Law Reform Committee (CLRC)'. Retrieved Mar 2, 2008, from http://www.ssm.com. my/clrc/clrc.htm

Suruhanjaya Syarikat Malaysia (SSM) (2009), 'Review of the Companies Act 1965 - Final Report by the Corporate Law Reform Committee'.

Tabone, N, and Baldacchino P.J. (2003), 'The Statutory Audit of Owner-Managed Companies in Malta', Managerial Auditing Journal, vol.18, no.5, pp. 387-398.

Tauringana, V. and Clarke, S. (2000), 'The Demand for External Auditing: managerial share Ownership, Size, Gearing and Liquidity Influences', Managerial Auditing Journal, vol. 15, no.4, pp. 160-168.

Teece, D.J., Pisano, G., Shuen, A., (1997), 'Dynamic capabilities and strategic management', Strategic Management Journal, vol.18, no.7, pp. 509-533. 
Ulrich, D., \& Barney, J. B. (1984), 'Perspectives in organizations: Resource dependence, efficiency, and Population', Academy of Management Review, vol.9, no.3, pp. 471-481.

Wallace, W. A. (1980), The economic role of the audit in free and regulated markets. New York. Touch Ross.

Wernerfelt, B. (1984), 'A Resource-Based View of the Firm', Strategic Management Journal, vol. 5, pp. 171-180.

Wignaraja, G. (2003), 'Promoting SME Exports in Developing Countries', Retrieved January 15, 2010, from http://www.oecd.org/dataoecd/12/54/20167784.pdf 